ISSN 1392-3196 / e-ISSN 2335-8947

Zemdirbyste-Agriculture, vol. 108, No. 4 (2021), p. 303-312

DOI 10.13080/z-a.2021.108.039

\title{
Determination of antagonistic potential of endophytic bacteria isolated from lettuce against lettuce white mould disease caused by Sclerotinia sclerotiorum
}

\author{
Soner SOYLU ${ }^{1}$, Merve KARA ${ }^{1}$, Aysun UYSAL ${ }^{2}$, Şener KURT ${ }^{1}$, Emine Mine SOYLU ${ }^{1}$ \\ ${ }^{1}$ Hatay Mustafa Kemal University, Faculty of Agriculture \\ Antakya 31034, Hatay, Turkey \\ E-mail: soylu@mku.edu.tr \\ ${ }^{2}$ Hatay Mustafa Kemal University, Centre for Implementation and Research of Plant Health Clinic \\ Antakya 31034, Hatay, Turkey
}

\begin{abstract}
In this study, biocontrol efficiency of endophytic bacterial isolates obtained from the leaf lettuce (Lactuca sativa $\mathrm{L}$.) healthy plants was investigated against white mould disease agent Sclerotinia sclerotiorum in vitro and in vivo conditions. Antagonistic efficiency of endophytic bacterial isolates was determined to inhibit mycelial growth and sclerotial germination, suppress disease incidence caused by S. sclerotiorum. A total of 48 endophytic bacterial isolates were isolated from different tissues of lettuce healthy plants. Mycelial growth and germination of sclerotia of S. sclerotiorum in vitro inhibited 18 bacterial isolates. Bacillus subtilis and B. amyloliquefaciens isolates were found to be the most efficient ones, which significantly inhibited the mycelial growth by $68.1-83.1 \%$, germination of sclerotia by $82.7-89.6 \%$ and suppressed disease incidence by $55.7-75 \%$ caused by $S$. sclerotiorum. In addition, the fungal mycelium close to the inhibition zone in dual culture was denser and darker in colour. B. subtilis and B. amyloliquefaciens isolates caused significant morphological alterations in hyphae such as hyphal shrivelling and perforation close to the inhibition zone in dual culture.

Significant suppression in the mycelial growth, sclerotial germination and disease incidence caused by endophytic bacterial isolates indicate that isolates of $B$. subtilis and B. amyloliquefaciens could be considered as possible biocontrol agents against soil-borne fungal diseases.
\end{abstract}

Key words: Lactuca sativa, antagonist, biological control, endophytes, Sclerotinia sclerotiorum.

\section{Introduction}

Leaf lettuce (Lactuca sativa L.) is one of the most economically important leafy vegetable crops worldwide. The leading producers of lettuce were Europe and North America; however, since the late $20^{\text {th }}$ century, lettuce production and consumption spread throughout the world. At present, the leading producer of lettuce in the world is China followed by the USA. Turkey, which ranks $10^{\text {th }}$ among the leading lettuce producing countries in the world, produced 500.000 tonnes from 23.335 ha area (FAOSTAT, 2019; http://www.fao.org/ faostat/en/\#data/QC). This crop is cultivated in several provinces of Turkey and Eastern Mediterranean region accounting for over $45 \%$ of Turkish production (Turkish Statistical Institute, 2021; https://biruni.tuik.gov.tr/ medas $/$ ? $\mathrm{kn}=92 \&$ locale $=$ tr). Lettuce production mainly occurs in three provinces (Adana, Mersin and Hatay) within this region.
The fungal pathogens in the genus Sclerotinia are worldwide distributed and attack several vegetable crops including lettuce (Rothmann, McLaren, 2018). Sclerotinia sclerotiorum (Lib) de Bary, a destructive fungal pathogen with an extensive host range infecting more than 400 plant species, causes white mould and leaf drop disease on the leafy green lettuce, which has an enormous economic impact on lettuce cultivation causing significant yield losses to growers worldwide (Ni et al., 2014). Disease agent causes remarkable yield losses of up to $60 \%$ in individual fields (Hao, Subbarao, 2005). In Turkey, S. sclerotiorum is also the predominant soil-borne fungal pathogen determined in the Eastern Mediterranean region surveyed (Soylu et al., 2017).

The most obvious signs of the disease are defined by a watery soft rot accompanied by the appearance of a white fluffy mycelial growth on the crown of infected

Please use the following format when citing the article:

Soylu S., Kara M., Uysal A., Kurt S., Soylu E. M. 2021. Determination of antagonistic potential of endophytic bacteria isolated from lettuce against lettuce white mould disease caused by Sclerotinia sclerotiorum. Zemdirbyste-Agriculture, 108 (4): $303-312$. DOI 10.13080/z-a.2021.108.039 
plant. Dark sclerotia are subsequently formed on infected plant parts and soil around roots. Sclerotia are overwintering fungal structures that resist environmental factors and fungicides and remain viable in the soil for many years (Ordóñez -Valencia et al., 2014).

To control lettuce white mould disease agent in Turkey, effective control measures are currently not available. Use of resistant cultivars, solarisation, drip irrigation, crop rotation and soil disinfections were major cultural practices offered for disease management (Collange et al., 2014). However, the fungicides registered against the fungal disease agent do not adequately control the diseases (Zhu et al., 2016). Since the disease agent has a wide host range and produces overwintering sclerotia that survive in soil for a long time, crop rotation is usually not an effective control practice against it (Rothmann, McLaren, 2018). Very few fungicides such as Dicloran, Iprodione and Vinclozolin are registered with a low level of disease control in most production areas (Derbyshire, Denton-Giles, 2016). The efficacies of these fungicides have been reduced due to their frequent uses in the areas, where intensive lettuce cultivation is carried out and due to their rapid degradation in soil (Collange et al., 2014). Public concern over frequent pesticide usage, pesticide residue on lettuce leaves, development of fungicide resistance and the need for a higher level of disease control promote non-chemical approaches for disease agent (Smolińska, Kowalska, 2018).

Because of the harmful side-effects of fungicides on the environment, eco-friendly agricultural practices using bacteria, fungi or actinomycetes have become an alternative to the chemical control of soilborne pathogens such as Sclerotinia (Chen et al., 2016). A number of bacterial biological control agents such as Paenibacillus alvei (Fatouros et al., 2018), Streptomyces spp. (Chen et al., 2016), Bacillus subtilis (Hu et al., 2014) and Burkholderia pyrrocinia (Lee et al., 2011) have been successfully used against $S$. sclerotiorum. The mechanisms for the suppression of pathogens by biological control agents include mycoparasitism, antagonism via production of secondary antimicrobial compounds, competition for space and resources, induction of plant resistance and antibiosis (Ahemad, Kibret, 2014).

Plants are hosts to a wide range of beneficial microorganisms such as fungal, bacterial and viral agents. Plant associated beneficial bacteria, also known as plant growth promoting bacteria (PGPB), either colonize epiphytically the rhizosphere (called rhizobacteria) or reside inside the plant tissue in a mutualistic relationship (called as endophytes) (Beneduzi et al., 2012; Sülü etal., 2016; Soylu, Bozkurt, 2019). Since PGPB multiply well enough and produce a wide range of antimicrobial compounds, the use of endophytic bacteria has been of high interest as biocontrol agents for a wide range of soilborne fungal diseases (Eljounaidi et al., 2016; Santoyo et al., 2016). Bacterial endophytes possess important role in plant growth promotion by increasing nutrient uptake and mineral solubilisation and protecting host plants against their potential pathogens inducing active disease resistance mechanisms (Ahemad, Kibret, 2014).

Although antagonistic potential and mode of mechanisms of epiphytic antagonist bacterial isolates have been studied against $S$. sclerotiorum in economically important crop plants such as rapeseed (Kamal et al., 2015), tomato (Abdeljalil et al., 2016) and lettuce (Chen et al., 2016; Fatouros et al., 2018; Oliver et al., 2019), to the best of our knowledge there is no research, which examined the use of endophytic bacterial species identified in this study for biological control of white mould disease of lettuce in vitro and in vivo. Amongst the endophytic bacterial species, especially Bacillus spp., there were the most studied biocontrol agents used for white mould disease.

The aim of this study was isolation, characterization and in vitro and in vivo evaluation of antagonistic properties of endophytic bacteria from inner parts of lettuce healthy plants for utilization as a possible biocontrol agent against white mould disease agent S. sclerotiorum. Efficacy of endophytic bacterial isolates on suppression of mycelial growth, the viability of sclerotia and disease incidence were investigated in vitro and in vivo. The possible mechanism of antagonism was also evaluated under the light microscope.

\section{Materials and methods}

Isolation and identification of fungal disease agents. During the disease survey conducted in the 2016-2017 growing season, Sclerotinia sclerotiorum was isolated from sclerotia developed on the infected leaf lettuce (Lactuca sativa, cultivar 'Göbekli') plants (Figure 1) growing in a small-scale organic farming field in Antakya district $\left(36^{\circ} 19^{\prime} 21^{\prime \prime} \mathrm{N}, 36^{\circ} 12^{\prime} 14^{\prime \prime} \mathrm{E}\right)$ of Hatay province of Turkey. Sclerotia were removed from infected plants, surface-disinfected and placed on potato sucrose agar (PDA) (Merck, Germany) supplemented with $50 \mathrm{mg} \mathrm{ml}^{-1}$ streptomycin sulphate and incubated at 25 $\pm 1^{\circ} \mathrm{C}$ temperature for 5-7 days. Isolation from surfacedisinfested sclerotia on PDA consistently yielded white mycelia with black sclerotia. For molecular analysis, pure fungal isolates were preserved on PDA plates and kept at $4^{\circ} \mathrm{C}$ temperature.

Representative isolates $(\mathrm{n}=10)$ on PDA plate were deposited in the Hatay Mustafa Kemal University BİSAK Microbial Culture Collection Centre (isolate Nos. MKUBK-LSs1-10). The identification of representative fungal isolate No. MKUBK-LSs5 was confirmed by analysing matrix-assisted laser desorption/ionizationtime of flight (MALDI-TOF) mass spectrometry (MS) MicroFlex LT (Bruker Daltonics, Germany). Fungal isolate was grown in sterile potato sucrose broth (PDB) for 3 days. Then mycelial masses were collected from nutrient broth and subjected for formic acid-ethanol extraction method according to manufacturer's instructions (Kurt et al., 2017). To confirm the morphological and MALDITOF MS identification, fungal genomic DNA was extracted from fungal mycelia of representative isolate No. MKUBK-LSs5 by using a DNeasy Plant Mini Kit (Qiagen Inc., Germany) according to manufacturer's instructions. The extracted DNA was then used as template for subsequent amplification using PCR. The internal transcribed spacer (ITS) region of rDNA of representative isolate No. MKUBK-LSs5 was amplified using primer ITS1/ITS4 and directly sequenced. The resulting ITS sequences were deposited in GenBank (accession No. MZ558499).

Isolation and identification of endophytic bacterial isolates. Endophytic bacterial isolates were obtained from leaves, stems and roots of apparently lettuce 48 healthy plants growing in 16 fields in 5 locations in Kirıkhan $\left(36^{\circ} 28^{\prime} 06^{\prime \prime} \mathrm{N}, 36^{\circ} 20^{\prime} 33^{\prime \prime} \mathrm{E}\right)$, Reyhanlı (36 $14^{\circ} 40^{\prime \prime}$ N, 36 $22^{\prime} 22^{\prime \prime}$ E; 36 $26^{\circ} 48^{\prime \prime}, \mathrm{N} 36^{\circ} 32^{\prime} 25^{\prime \prime}$ E) and Antakya (36 $19^{\prime} 16^{\prime \prime} \mathrm{N}, 36^{\circ} 12^{\prime} 45^{\prime \prime} \mathrm{E}$; 36 $\left.20^{\circ} 26^{\prime \prime} \mathrm{N}, 36^{\circ} 14^{\prime} 20^{\prime \prime} \mathrm{E}\right)$ districts of Hatay province, Turkey. The entire plants 

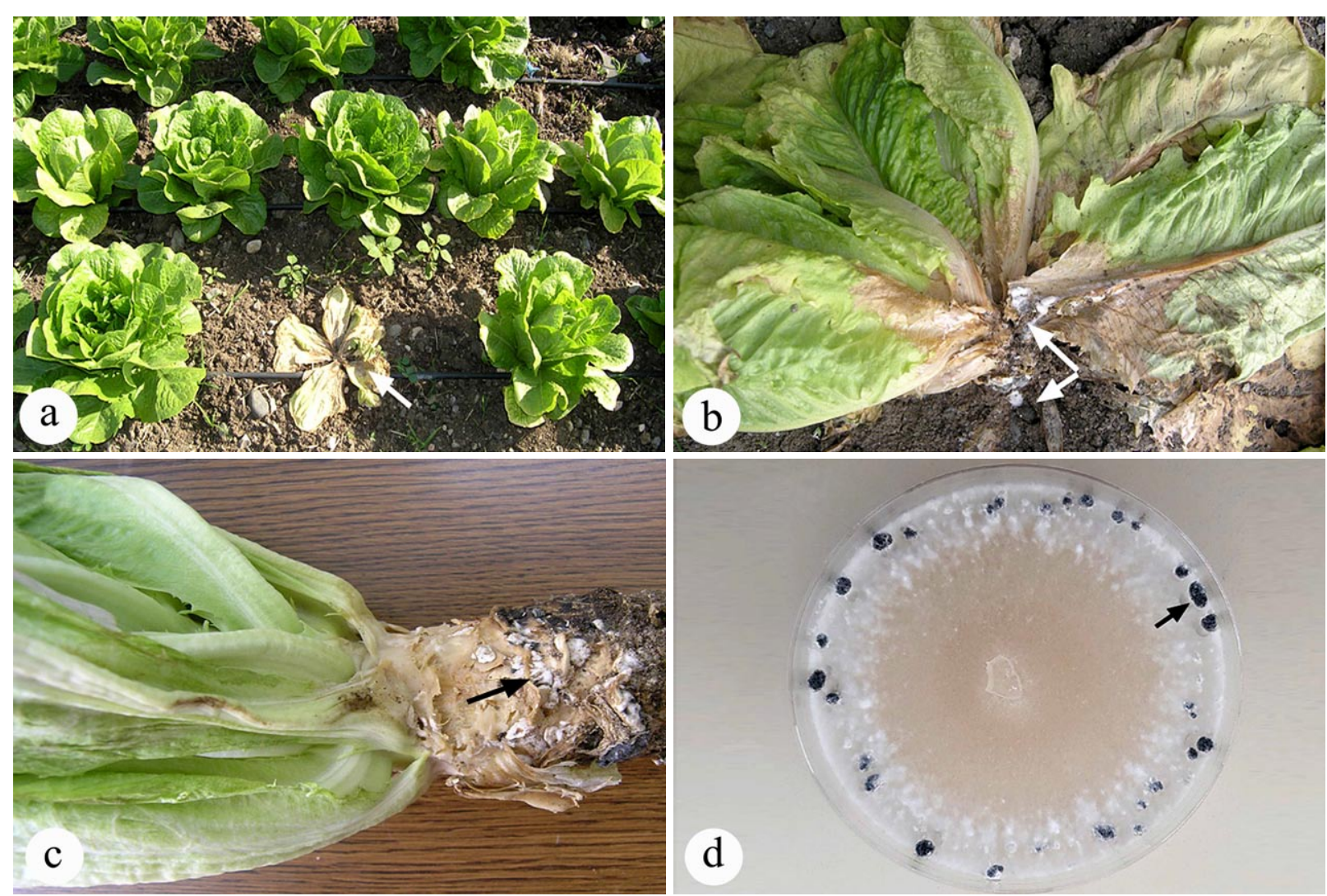

Note. Typical lettuce white mould and drop disease causing the lower leaves to wilt and drop to the soil surface (a, b); the black sclerotia of $S$. sclerotiorum (arrows) on crown, leaves and stem of infected lettuce plants and soil surface (b, c); mycelial growth and formation of sclerotia (arrow) on PDA (d).

Figure 1. Lettuce plants infected with white mould and drop disease agent Sclerotinia sclerotiorum

were flushed with running tap water to remove the soil and rinsed with sterile distilled water (SDW). Roots, stems and leaves of healthy plants were separated. All samples were subjected to surface sterilization procedure and macerated individually in $10 \mathrm{mM} \mathrm{MgCl}$ (magnesium chloride). Then serially diluted suspensions were spread onto plates with King B (KB) agar (Merck). Surface sterilised healthy tissues were also aseptically cut into small fragments and inside of each tissue were imprinted by touching directly on the KB agar according to Duman and Soylu (2019). All Petri plates were incubated at 25 $\pm 1^{\circ} \mathrm{C}$ temperature for 2 days. Based on morphological characteristics, representative bacterial isolates were selected from a single colony, re-streaked on fresh $\mathrm{KB}$ agar and maintained at $4^{\circ} \mathrm{C}$ temperature for routine in vitro tests. For long-term storage, all bacterial isolates were kept at $-80^{\circ} \mathrm{C}$ temperature in $40 \%\left(\mathrm{v} \mathrm{v}^{-1}\right)$ glycerol solution. For hypersensitive reaction (HR), putative endophytic bacterial isolates were tested on tobacco (Nicotiana tabacum L.) plant leaves and potato soft rot test on potato slices. As putative antagonist bacterial isolates, only isolates that did not cause HR and soft rot symptoms were selected.

Following preliminary characterization of putative antagonist bacterial isolates by applying biochemical tests, MALDI-TOF MS based identification was used to confirm the identity of putative antagonist bacterial isolates. In many cases, MALDI-TOF MS based identifications, using peptide mass fingerprint, have shown resolution and reproducibility, which is better than gel-based protein or DNA finger printing techniques (Singhal et al., 2015).
The bacterial mass from the pure colonies developed for 24-36 h on tryptic soy agar (TSA) medium (Merck) was subjected to ethanol-formic acid-pure acetonitrile protein extraction according to manufacturer's instructions. A total of $1 \mu \mathrm{l}$ of the extract was dropped onto the MALDI target, dried and overlaid with $1 \mu \mathrm{l}$ matrix solution, as described previously (Duman, Soylu, 2019). Microorganism library was used as software BIOTYPER, version 1.1 (Bruker Daltonics GmbH, Germany).

Determination of antagonistic activities of endophytic bacterial isolates on mycelial growth. Antagonistic activity of individual endophytic bacterial isolates was determined on PDA on Petri plates by using a dual culture test (Pane et al., 2012). A loopful of putative bacterial isolates was streaked on Petri plates containing PDA and pre-incubated at $25 \pm 1^{\circ} \mathrm{C}$ temperature for 2 days. Mycelial plugs (5 $\mathrm{mm}$ diameter) of the fungal pathogen were placed on the same plates approximately $4 \mathrm{~cm}$ away from the bacterial mass $48 \mathrm{~h}$ after incubation (Figure 2).

As control plates, mycelial plugs of fungal pathogen without bacterial isolates were used. All Petri plates were incubated at $25 \pm 1{ }^{\circ} \mathrm{C}$ temperature for $4-5$ days. The radius of fungal growth towards the bacteria on dual culture and control Petri plates was measured in $\mathrm{mm}$ 4-5 days after inoculation and mycelial growth inhibition (MGI) percentage - in relation to the control by using the formula:

MGI $(\%)=[(\mathrm{MGc}-\mathrm{MGt}) / \mathrm{MGc}] \times 100$, where MGc and MGt are mycelial growth in control and bacterial isolate drawn Petri plates, respectively. 


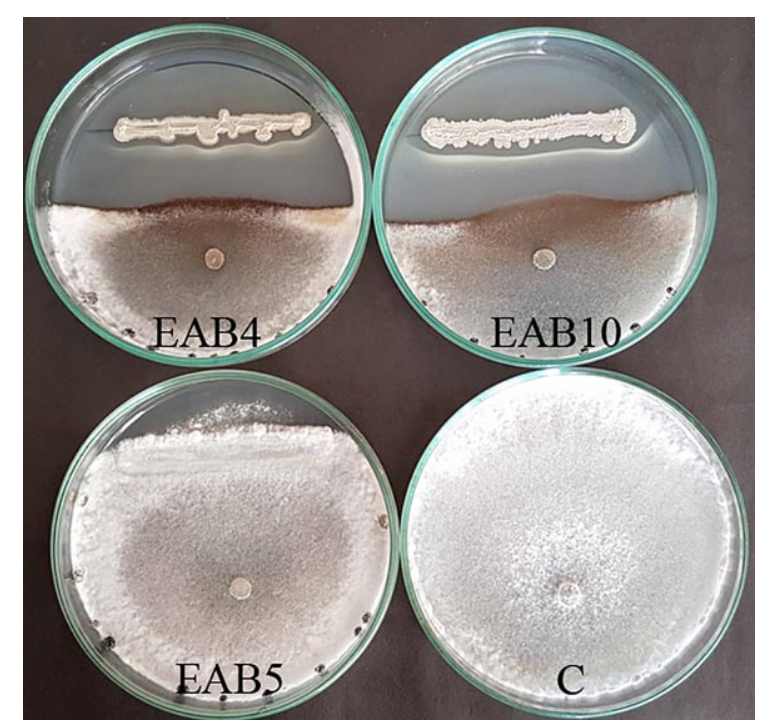

Note. Strong (Bacillus amyloliquefaciens EAB4 and B. subtilis EAB10 isolates) and weak (Sphingomonas yanoikuyae EAB5 isolate) inhibition of mycelial growth on dual culture plates; $\mathrm{C}$ - mycelial growth of pathogen in the absence of antagonist bacterial isolate.

Figure 2. Inhibition of mycelial growth of Sclerotinia sclerotiorum by antagonist bacterial isolates in dual culture

Three Petri plates were used for each bacterial isolate, and the dual culture test was repeated at least twice. To characterise the nature of antagonistic effect of diffused metabolite(s) from bacterial isolates, agar plugs taken from the near edge of inhibition zones were placed on fresh PDA plate and incubated at $25 \pm 1{ }^{\circ} \mathrm{C}$ temperature for 3 days. The antagonistic effect was considered fungistatic, if mycelial growth from the plug occurred or fungicidal and if no pathogen growth occurred.

Determination of antagonistic activities of endophytic bacterial isolates on sclerotia viability. Antagonistic activities of the endophytes were also tested on the viability of sclerotia (Soylu et al., 2007). Obtained from the overnight cultures and suspended in SDW at $10^{8}$ CFU ml ${ }^{-1}$ concentration, $5 \mathrm{ml}$ of bacterial suspension was mixed with $10 \mathrm{~g}$ of steam-sterilized natural sandy soil and added into Petri plates. Fungal sclerotia were gently removed from 3-week-old PDA culture grown at $25 \pm 1^{\circ} \mathrm{C}$ temperature. Sclerotia $(n=10)$ were buried at $1 \mathrm{~cm}$ depth in inoculated soil. All treated Petri plates were incubated at $25 \pm 1{ }^{\circ} \mathrm{C}$ temperature for 4 weeks. As control, sclerotia in sandy soil treated with SDW was used. The viability of treated sclerotia was assessed, and the number of sclerotia showing mycelial growth on PDA plates was evaluated 4 weeks after incubation at $20^{\circ} \mathrm{C}$ temperature.

Inhibition percentage of sclerotial germination was calculated by counting germinating sclerotia showing mycelial growth $(n=10)$ sown into soil by using the formula:

Inhibition $(\%)=[(\mathrm{GSc}-\mathrm{GSt}) / \mathrm{GSc}] \times 100$, where GSc and GSt are germinating sclerotia showing mycelial growth in control treatment and bacterial suspension treated sandy soil. For each bacterial isolate, three plates were used, and the experiments were repeated at least twice.

Determination of in vivo antagonistic activities of endophytic bacterial isolates on disease incidence.
In vivo bioassays studies were conducted in sterile commercial steam-sterilized peat soil (Soylu et al., 2007). Inoculum of $S$. sclerotiorum was prepared by culturing disease agent on oat grains. Oat grains $(50 \mathrm{~g})$ were placed in $500 \mathrm{ml}$ flasks, filled with $100 \mathrm{ml}$ PDP solution and autoclaved at $121^{\circ} \mathrm{C}$ temperature for $30 \mathrm{~min}$. Autoclaved oat seeds in flasks were then inoculated with 20 agar discs ( $6 \mathrm{~mm}$ in diameter) containing fungal mycelia taken from 6 -days-old fungal cultures. Flasks were incubated at $25^{\circ} \mathrm{C}$ temperature in the dark for 2 weeks. As control, inoculum of autoclaved oat seeds without pathogen was considered. To confirm the presence or absence of $S$. sclerotiorum inoculum, inoculated oat grains were cultured on PDA plates and observed for pathogen growth. The resulting fungal oat inoculum was mixed with steam-sterilized peat soil in a sterile plastic bag before sowing the cultivar 'Göbekli' lettuce seeds, as reported previously (Pane et al., 2012). The S. sclerotiorum inoculum contained 5.3 CFU g-1 soil.

Pots $(7 \mathrm{~cm}$ diameter) were filled with inoculated and non-inoculated peat soil (100 g). The bacterial suspension $\left(10^{8} \mathrm{CFU} \mathrm{ml}^{-1}\right)$ was prepared in nutrient broth (NB) solution, and then each pot $(\mathrm{n}=3)$ was drenched with $20 \mathrm{ml}$ of antagonist bacterial suspension $\left(10^{8} \mathrm{CFU}\right.$ $\mathrm{ml}^{-1}$ ). Experiments were arranged in a growth chamber at $25 \pm 1{ }^{\circ} \mathrm{C}$ temperature following a completely randomized block design. One week after bacterial treatment, the surface sterilized lettuce seeds $(n=20)$ were sown in the bacterial suspension treated peat soil. The pots were kept covered with plastic stretch wrap film and maintained for 10 weeks. As control treatment, pathogen non-inoculated or inoculated non-amended with the antagonist bacterial suspension soils were considered. The pots were watered with SDW twice weekly. Emerging and surviving healthy plants (without any sign of disease) from each treatment were recorded.

Protection percentage rate was calculated by counting the seedlings that developed and showed signs of disease symptoms from the total seeds $(n=20)$ planted in soil inoculated with $S$. sclerotiorum by using the formula:

Protection $(\%)=[(\mathrm{DSc}-\mathrm{DSt}) / \mathrm{DSc}] \times 100$, where DSc and DSt are diseased seedlings in control treatment and bacterial suspension treated peat soil (Soylu et al., 2007). For each bacterial isolate, three pots were used, and the experiments were repeated at least twice.

Morphological changes caused by endophytic bacteria on hyphal morphology. Determination of antagonistic effect of endophytes on hyphal morphology of fungal pathogen was studied 7 days after inoculation with co-culturing both microorganisms side by side on the same PDA plates. Thin layers $\left(3-4 \mathrm{~cm}^{2}\right)$ of agar blocks were cut from the adjacent site to the inhibition zone caused by endophytic bacterial isolates, placed on microscope glass slides, and hyphae at the adjacent site to the inhibition zone were examined under Nomarski DICequipped light microscope (Olympus BX51, Japan).

Statistical analysis. For all calculations, SPSS Statistics for Windows, version 17.0 (SPSS Inc., USA) was performed. Data from the in vitro and in vivo assays were processed with the one-way analysis of variance (ANOVA). When the ANOVA was significant at $P \leq 0.05$, means were separated with Duncan's multiple range test. 


\section{Results and discussion}

Isolation, identification and determination of antagonistic potential of endophytic bacterial isolates. A total of 48 putative endophytic bacterial isolates were isolated and purified from lettuce 45 healthy plants collected from 15 fields in three districts of Hatay province. To suppress fungal growth using the dual culture test, these isolates were tested individually. Among the tested 48 putative bacterial isolates (data not shown), 18 antagonist bacterial isolates $(37.5 \%)$ were found to cause inhibition zones by inhibiting the mycelial growth of $S$. sclerotiorum to a varying degree. Among the 18 antagonistic bacterial isolates, 8 isolates $(44.4 \%)$ obtained from seven fields (wheat-cotton polyculture), 3 isolates (16.6\%) from three fields (wheat-maize polyculture), 4 isolates $(22.2 \%)$ from four fields (carrottomato polyculture) and 3 isolates (16.6\%) from one field (wheat-pepper polyculture) (Table 1).
Based on the morphological characteristics and MALDI-TOF analysis, antagonist endophytes showing clear antagonism in vitro against $S$. sclerotiorum were identified at the species level. Based on MALDI-TOF analysis, endophytic bacteria were identified as Bacillus spp. (8), Stenotrophomona maltophilia (2) and one each as Brevibacillus laterosporus, Lactobacillus acidophilus, Pantoea agglomerans, Sphingomonas yanoikuyae, Pseudomonas fluorescence, Enterobacter cloacae, Rhizobium radiobacter and Serratia marcescens (Table 1). The identification of bacterial and fungal species using proteomic approach such as MALDI-TOF MS has proven be a reliable bacterial identification system becoming popular as an alternative to chromatographic and even DNA-dependent molecular methods (Panda et al., 2013). In several studies, MALDI-TOF MS has been found to be more accurate for bacterial species identification than conventional diagnostic methods (Singhal et al., 2015).

Table 1. The antagonistic potential of endophytic bacterial isolates on the inhibition of mycelial growth of Sclerotinia sclerotiorum in vitro

\begin{tabular}{|c|c|c|c|}
\hline Bacterial species & $\begin{array}{l}\text { Origin } \\
\text { (district) }\end{array}$ & $\begin{array}{l}\text { Mycelial growth } \\
\mathrm{mm}\end{array}$ & $\begin{array}{c}\text { Inhibition } \\
\% \\
\end{array}$ \\
\hline Serratia marcescens EAB1 & Hassa & $31.0 \mathrm{~g}$ & 39.6 \\
\hline Bacillus subtilis EAB2 & Antakya & $16.0 \mathrm{~h}$ & 68.8 \\
\hline Bacillus subtilis EAB3 & Antakya & $14.7 \mathrm{hi}$ & 71.4 \\
\hline Bacillus amyloliquefaciens EAB4 & Kirıkhan & $15.0 \mathrm{~h}$ & 70.8 \\
\hline Sphingomonas yanoikuyae EAB5 & Kirıkhan & $43.3 \mathrm{~b}-\mathrm{d}$ & 15.6 \\
\hline Stenotrophomona maltophilia EAB6 & Kirıkhan & $37.7 \mathrm{~d}-\mathrm{f}$ & 26.6 \\
\hline Bacillus amyloliquefaciens EAB7 & Antakya & $16.3 \mathrm{~h}$ & 68.2 \\
\hline Bacillus subtilis EAB8 & Antakya & $13.7 \mathrm{~h}-\mathrm{i}$ & 73.4 \\
\hline Bacillus subtilis EAB9 & Antakya & $9.3 \mathrm{i}$ & 81.8 \\
\hline Bacillus subtilis EAB10 & Antakya & $8.7 \mathrm{k}$ & 83.1 \\
\hline Pantoe agglomerans EAB11 & Reyhanlı & $40.0 \mathrm{~b}-\mathrm{e}$ & 22.1 \\
\hline Stenotrophomonas maltophilia EAB12 & Reyhanlı & $38.3 \mathrm{c}-\mathrm{f}$ & 25.3 \\
\hline Pseudomonas fluorescence EAB13 & Reyhanlı & $45.0 \mathrm{~b}$ & 12.3 \\
\hline Bacillus simplex EAB14 & Reyhanlı & $34.0 \mathrm{fg}$ & 33.8 \\
\hline Brevibacillus laterosporus EAB15 & Hassa & $36.0 \mathrm{e}-\mathrm{g}$ & 29.9 \\
\hline Enterobacter cloacae EAB16 & Hassa & $43.0 \mathrm{~b}-\mathrm{d}$ & 16.2 \\
\hline Lactobacillus acidophilus EAB17 & Kirikhan & $33.0 \mathrm{fg}$ & 35.7 \\
\hline Rhizobium radiobacter $\mathrm{EAB} 18$ & Antakya & $44.0 \mathrm{bc}$ & 14.3 \\
\hline S. sclerotiorum (control) & Antakya & $51.3 \mathrm{a}$ & 0.0 \\
\hline
\end{tabular}

Note. Mean values of mycelial growth given in column followed by the same letters are not significantly different.

Given several proven track records of the accuracy of the MALDI-TOF bacterial identification method, it was assumed that endophytic antagonist bacterial isolates used in this study were identified correctly. Several species belonging to these genera were reported as the most reported as endophytic biocontrol agents (Santoyo et al., 2016; Sülü et al., 2016). In recent years, researchers have started to focus on the biocontrol potential of endophytic bacteria against different plant disease agents (Eljounaidi et al., 2016).

Antifungal activity of endophytic bacterial on mycelial growth and germination of sclerotia. Soilborne fungal pathogens cause considerable damage to agriculturally important crops, and they have been often targeted in biological control studies. Therefore, antagonistic activities of selected 18 bacterial isolates were further screened against $S$. sclerotiorum (Table 1). Hyphal growth of disease agent was significantly $(P<0.01)$ suppressed by 18 endophytic bacterial isolates obtained from lettuce healthy plant tissues. Among the tested bacterial isolates, the most efficient isolate was found to be $B$. subtilis EAB10, which significantly inhibited the growth of S. sclerotiorum (83.1\%) from the others (Figure 2). Notably, using dual culture test on PDA, mycelial growth was also suppressed by other isolates of Bacillus spp.: B. subtilis EAB9 (81.8\%), B. subtilis EAB8 (73.4\%), B. subtilis EAB3 (71.4\%), B. amyloliquefaciens EAB4 (70.8\%), B. subtilis EAB2 $(68.8 \%)$ and $B$. amyloliquefaciens EAB7 (68.2\%) (Table 1, Figure 2).

In previous studies, epiphytic bacterial isolates of Pseudomonas spp. (Soylu et al., 2005; Loewen et al., 2014; Oliver et al., 2019), Burkholderia spp. (Lee et al., 2011), Bacillus spp. (Soylu et al., 2005; Pane etal., 2012), Paenibacillus alvei (Fatouros et al., 2018) and Streptomyces (Chen et al., 2016) were isolated from plant surface or soil and found to inhibit in vitro fungal growth. However, this is the first study that evaluated the antagonistic potential of endophytic bacterial isolates to manage disease agent on lettuce in vitro and in vivo.

Bacillus species may produce a wide range of secondary metabolites (Zhao et al. 2012). Biocontrol potential of epiphytic bacterial species of B. subtilis, $B$. amyloliquefaciens and B. pumilis, living in and around 
roots of a wide range of crop plants, was tested against root-infecting soil-borne fungal disease agents such as Macrophomina phaseolina, Sclerotinia spp., Rhizoctonia solani and Fusarium spp. (Kamal et al., 2015; Abdeljalil et al., 2016; Imriz et al., 2020).

Nowadays, for controlling pathogens, there is considerable interest in developing biological strategies using endophytic biological control agents with antimicrobial activities (Eljounaidi et al., 2016). Chen et al. (2014) isolated endophytic isolate of B. subtilis from the rapeseed plant. Bacterial isolate was then evaluated for its suppressive potential on the hyphal growth and sclerotial germination of $S$. sclerotiorum.

On dual culture plate, $B$. subtilis and $B$. amyloliquefaciens isolates caused considerable morphological changes on the fungal hyphae close to the inhibition zone, which were denser and darker in colour (Figures 2 and 3a). When lysed dark mycelial plugs close to the inhibition zone were placed on fresh PDA plate in the absence of antagonist bacteria, fungus typically failed to grow on the PDA plate (Figure 3b). Also, no mycelial growth was observed, when healthy mycelial plugs were placed on the inhibition zone caused by isolates of B. subtilis or B. amyloliquefaciens (Figure 3a). This test confirms that diffusible metabolite(s) of $B$. subtilis or $B$. amyloliquefaciens isolate were fungicidal to S. sclerotiorum. However, typical mycelial growth was observed, when the unaffected white mycelial plugs (Figure 3c) transferred fresh PDA in the absence of antagonist bacteria (Figure 3d).

Light microscopic observations on affected hyphae from adjacent site to the inhibition zone caused by $B$. subtilis EAB10 isolate (Figure 4 a) showed loss of integrity, hyphal shrivelling and perforation, mycelial degradation and hyphal lysis and fragmentation (Figure 4b, c) compared with thick, elongated and normal mycelial growth in control plates (Figure 4d). In addition, abnormal appearance and leakage of the fungal cell contents from hyphal tips and cells around the inhibition zone were frequently observed (Figure $4 \mathrm{~b}$, c). Such abnormalities in fungal hyphae could be caused by bacterial origin secondary metabolites and/or diffusible lytic enzyme(s) such as chitinase, glucanase and proteases synthesised during antagonism suggested

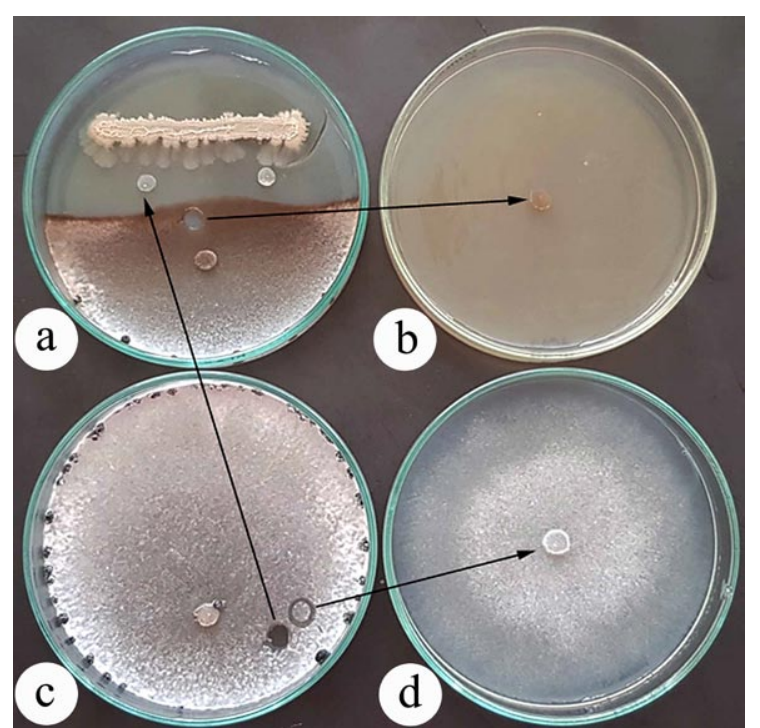

Note. Inhibition of healthy hyphal discs (arrows) on the inhibition zone, where bacterial metabolite(s) gradually diffused (a); the dark coloured affected hyphal disc $(*)(b)$, taken from interaction region adjacent to the clear zone of inhibition caused by $B$. subtilis AEB10 (a), was unable to grow on PDA plate (b) indicating fungicidal activity of the bacterial metabolite(s); mycelial growth of pathogen without bacterial isolate in control plates $(\mathrm{c}, \mathrm{d})$.

Figure 3. Fungicidal activity of the inhibition zone caused by Bacillus isolate in dual culture

earlier (Geraldine et al., 2013). The degenerated hyphae and lysed cells in fungal hyphae strongly supported the role of cell wall degrading enzyme(s) in the antifungal activity of these isolates (Figure 4).

Since chitin and $\beta$-glucans are both main constituents of fungal walls of Oomycetes and Sclerotinia species (Hernández-León et al., 2015), malformation observed in fungal hyphae caused by Bacillus isolates, especially by $B$. subtilis EAB 10 and B. amyloliquefaciens EAB4, could be one of the possible antagonistic mechanisms against $S$. sclerotiorum. The contribution of cell wall degrading enzymes to antifungal activity
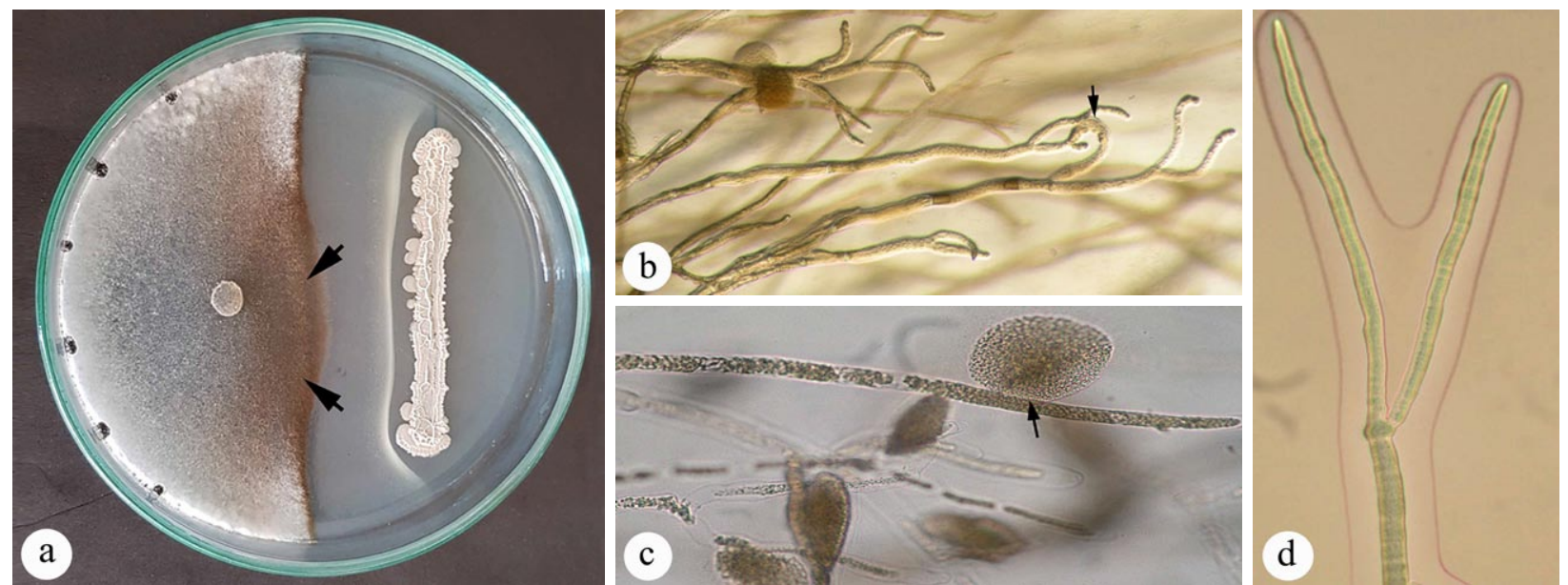

Note. Dark coloured affected hypha at interaction region (arrows) adjacent to the clear zone of inhibition caused by B. subtilis AEB 10 (a); morphological deformities and lysis of fungal hyphae (arrow) (b, c); healthy thick fungal hyphae in control plate (d).

Figure 4. Changes in the structural integrity of fungal hyphae adjacent to the inhibition zone caused by Bacillus subtilis AEB10 isolate 
against different plant disease agents and sclerotia forming fungal disease agents has been suggested for certain isolates of $B$. subtilis, B. amyloliquefaciens and B. mojavensis (Ahemad, Kibret, 2014; Youcef-Ali et al., 2014). In previous studies (Gupta et al., 2001), Pseudomonas sp. and Burkholderia cepacia have been reported to cause similar mycelial deformities and inhibition of mycelial growth of charcoal rot disease agent (M. phaseolina) and white mould disease caused by $S$. sclerotiorum following the production of antifungal metabolites in vitro. Cell wall degrading enzymes such as chitinase and glucanase produced by $B$. subtilis isolates may degrade the major fungal cell wall composed of chitin, glucosidic bonds and $\beta$-1,3-glucan (Kumar et al., 2012; Hernández-León et al., 2015). Myriocin, produced by $B$. amyloliquefaciens LZN01 isolate, was reported to suppress the mycelial growth of Fusarium oxysporum f. sp. niveum. Microscopical observation revealed that myriocin decreased the membrane fluidity and destroyed the membrane integrity. Severe morphological changes, including conidial shrinkage, the appearance of larger vacuoles and inhomogeneity of electron density, were reported to occur in myriocin-treated cells (Wang et al., 2021).

The antagonistic effects of all bacterial isolates on the viability of over-wintering fungal structure called sclerotia was also assessed (Table 2). Among 18 isolates, 13 bacterial isolates significantly inhibited myceliogenic germination of fungal sclerotia compared to the control treatment. The highest inhibitory activities (82.8-89.7\%) against sclerotial germination was shown by isolates of B. subtilis EAB10, EAB8 and B. amyloliquefaciens EAB4. In previously conducted study (Ji et al., 2013), B. amyloliquefaciens cell-free cultures suppressed mycelial growth and germination of sclerotia of S. sclerotiorum.

Table 2. The antifungal effect of endophytic bacterial isolates on the germination of sclerotia of Sclerotinia sclerotiorum in vitro

\begin{tabular}{|c|c|c|}
\hline Bacterial species & Number of germinating sclerotia & Inhibition $\%$ \\
\hline Serratia marcescens EAB1 & $6.7 \mathrm{ef}$ & 31.1 \\
\hline Bacillus subtilis EAB2 & $4.7 \mathrm{~cd}$ & 51.7 \\
\hline Bacillus subtilis EAB3 & $3.7 \mathrm{bc}$ & 62.1 \\
\hline Bacillus amyloliquefaciens EAB4 & $1.7 \mathrm{a}$ & 82.8 \\
\hline Sphingomonas yanoikuyae EAB5 & $8.3 \mathrm{f}-\mathrm{h}$ & 13.8 \\
\hline Stenotrophomona maltophilia EAB6 & 6.7 ef & 31.1 \\
\hline Bacillus amyloliquefaciens EAB7 & $2.7 \mathrm{ab}$ & 72.4 \\
\hline Bacillus subtilis EAB8 & $1.3 \mathrm{a}$ & 86.2 \\
\hline Bacillus subtilis EAB9 & $2.3 \mathrm{ab}$ & 75.9 \\
\hline Bacillus subtilis EAB10 & $1.0 \mathrm{a}$ & 89.7 \\
\hline Pantoe agglomerans EAB11 & $7.7 \mathrm{e}-\mathrm{g}$ & 20.7 \\
\hline Stenotrophomonas maltophilia EAB12 & $8.0 \mathrm{f}-\mathrm{h}$ & 17.3 \\
\hline Pseudomonas fluorescence EAB13 & $9.0 \mathrm{gh}$ & 6.9 \\
\hline Bacillus simplex EAB14 & $6.7 \mathrm{ef}$ & 31.1 \\
\hline Brevibacillus laterosporus EAB15 & $6.0 \mathrm{de}$ & 38.0 \\
\hline Enterobacter cloacae EAB16 & $8.7 \mathrm{gh}$ & 10.4 \\
\hline Lactobacillus acidophilus EAB 17 & $6.7 \mathrm{ef}$ & 31.1 \\
\hline Rhizobium radiobacter $\mathrm{EAB} 18$ & $9.3 \mathrm{gh}$ & 3.5 \\
\hline Sterile distilled water (SDW) only & $9.7 \mathrm{~h}$ & - \\
\hline
\end{tabular}

Note. Values are the mean number of germinating sclerotia showing mycelial growth over an initial number of sclerotia $(\mathrm{n}=10)$ placed into soil; mean values followed by the same letters are not significantly different.

Suppression of disease development in vivo. Most of the conducted biological control studies for white mould disease focused on the antagonistic efficacy of bacterial isolates in vitro tests. In this study, bacterial isolates were also investigated for disease suppression in vivo. In control treatment, fungal agent caused significant disease incidence on lettuce seedlings. The number of germinated seeds (\%) and seedling development were significantly higher in inoculated soil drenched with the suspension of endophytic bacterial isolates (Table 3).

Table 3. The antagonistic potential of endophytic bacterial isolates on the disease incidence caused by Sclerotinia sclerotiorum in vivo

\begin{tabular}{lcc}
\hline \multicolumn{1}{c}{ Bacterial species } & Number of surviving plants & Protection \% \\
\hline Serratia marcescens EAB1 & $7.0 \mathrm{e}$ & 24.9 \\
Bacillus subtilis EAB2 & $11.0 \mathrm{f}$ & 48.0 \\
Bacillus subtilis EAB3 & $13.3 \mathrm{gh}$ & 61.3 \\
Bacillus amyloliquefaciens EAB4 & $13.0 \mathrm{f}-\mathrm{h}$ & 59.5 \\
Sphingomonas yanoikuyae EAB5 & $3.7 \mathrm{a}-\mathrm{c}$ & 5.8 \\
Stenotrophomona maltophilia EAB6 & $5.7 \mathrm{c}-\mathrm{e}$ & 17.3 \\
Bacillus amyloliquefaciens EAB7 & $12.3 \mathrm{fg}$ & 55.5 \\
Bacillus subtilis EAB8 & $13.7 \mathrm{~g}-\mathrm{i}$ & 63.6 \\
Bacillus subtilis EAB9 & $14.7 \mathrm{hi}$ & 69.4 \\
Bacillus subtilis EAB10 & $15.7 \mathrm{i}$ & 75.1 \\
Pantoe agglomerans EAB11 & $4.7 \mathrm{a}-\mathrm{d}$ & 11.6 \\
Stenotrophomonas maltophilia EAB12 & $6.0 \mathrm{de}$ & 19.1 \\
Pseudomonas fluorescence EAB13 & $4.0 \mathrm{a}-\mathrm{d}$ & 7.5 \\
Bacillus simplex EAB14 & $7.0 \mathrm{e}$ & 24.9 \\
Brevibacillus laterosporus EAB15 & $5.3 \mathrm{~b}-\mathrm{e}$ & 15.0 \\
Enterobacter cloacae EAB16 & $4.3 \mathrm{a}-\mathrm{d}$ & 9.2 \\
Lactobacillus acidophilus EAB17 & $7.3 \mathrm{e}$ & 26.6 \\
Rhizobium radiobacter EAB18 & $3.3 \mathrm{ab}$ \\
\hline S. sclerotiorum & $2.7 \mathrm{a}$ \\
\hline Note Values are the num & 3.5 \\
\hline
\end{tabular}

Note. Values are the number of emerging and surviving healthy seedlings over an initial number of seeds $(\mathrm{n}=20)$ sown into soil inoculated with S. sclerotiorum; mean values followed by the same letters are not significantly different. 
Apart from isolates Sphingomonas yanoikuyae EAB5, Pantoea agglomerans EAB11, Pseudomonas fluorescence EAB13, Enterobacter cloacae EAB16 and Rhizobium radiobacter EAB18, amendment of infested soil with 13 different bacterial isolates significantly promoted plant survival in comparison to pathogen treated soil without bacterial inoculation (control treatment) (Table 3). Six isolates increased the number of surviving seedlings more than $50 \%$. In addition, the numbers of surviving seedlings in the soil treated with isolates of $B$. subtilis EAB8, EAB9 and EAB10 were significantly higher $(P<0.05)$ than those observed in the soil amended with other isolates.

\section{Conclusions}

1. Among the tested 48 putative bacterial isolates, 18 antagonist bacterial isolates were found to cause inhibition zones by inhibiting the mycelial growth of Sclerotinia sclerotiorum to a varying degree in dual culture.

3. Based on the morphological characteristics and MALDI-TOF mass spectrometry (MS) analysis, endophytic bacteria were identified as Bacillus spp. (10), Stenotrophomona maltophilia (2) and one each as Pantoea agglomerans, Sphingomonas yanoikuyae, Pseudomonas fluorescence, Enterobacter cloacae, Rhizobium radiobacter and Serratia marcescens.

4. The highest mycelial growth inhibition was caused by $B$. subtilis EAB10 (83.11\%), which was followed by isolates of $B$. subtilis EAB9 (81.82\%), B. subtilis EAB8 (73.37\%), B. subtilis EAB3 (71.42\%), B. amyloliquefaciens EAB4 (70.78\%), B. subtilis EAB2 (68.83\%) and B. amyloliquefaciens EAB7 (68.19\%).

5. On dual culture plates, all B. subtilis and $B$. amyloliquefaciens isolates caused considerable morphological changes such as loss of integrity, hyphal shrivelling and perforation, mycelial degradation and hyphal lysis and fragmentation on the fungal hyphae close to the inhibition zone. Vitality test confirmed that diffusible metabolite(s) produced by all B. subtilis and B. amyloliquefaciens isolates were clearly fungicidal to S. sclerotiorum.

6. Among 18 isolates, 13 bacterial isolates also significantly inhibited myceliogenic germination of fungal sclerotia compared to the control treatment without bacterial inoculation. The isolates of B. subtilis EAB10, EAB8 and B. amyloliquefaciens EAB4 were recorded to possess the highest inhibitory activities (82.8-89.7\%) against sclerotial germination.

7. Bacterial isolates were also investigated for disease suppression in vivo. Apart from isolates of Sphingomonas yanoikuyae EAB5, Pantoea agglomerans EAB11,Pseudomonasfluorescence EAB13,Enterobacter cloacae EAB16 and Rhizobium radiobacter EAB18, amendment of infested soil with 13 different bacterial isolates suppressed disease incidence by $55.7-75 \%$.

8. Although the nature and identity of the antifungal compound(s) were not studied in detail, overall results suggest that suppression of disease incidence caused by $S$. sclerotiorum might be resulted by the production of antifungal compound(s), which caused inhibition in mycelial growth, sclerotial germination, disease incidence and morphological deformities of fungal hyphae. These observations are significant in the light of the attractive role of Bacillus spp. in the biocontrol of S. sclerotiorum. Significant suppression in the mycelial growth, sclerotial germination and disease incidence caused by endophytic bacterial isolates indicates that isolates of B. subtilis and B. amyloliquefaciens could be considered as possible biocontrol agents against soilborne fungal disease.

Received 06052021

Accepted 06092021

\section{References}

Abdeljalil N. O.-B., Vallance J., Gerbore J., Rey P., DaamiRemadi M. 2016. Biosuppression of Sclerotinia stem rot of tomato and biostimulation of plant growth using tomatoassociated rhizobacteria. Journal of Plant Pathology and Microbiology, 7 (2): 331. https://doi.org/10.4172/2157-7471.1000331

Ahemad M., Kibret M. 2014. Mechanisms and applications of plant growth promoting rhizobacteria: current perspective. Journal of King Saud University - Science, 26 (1): 1-20. https://doi.org/10.1016/j.jksus.2013.05.001

Beneduzi A., Ambrosini A., Passaglia L. M. P. 2012. Plant growth-promoting rhizobacteria (PGPR): their potential as antagonists and biocontrol agents. Genetics and Molecular Biology, 35 (4): 1044-1051. https://doi.org/10.1590/S1415-47572012000600020

Chen Y., Gao X., Chen Y., Qin H., Huang L., Han Q. 2014. Inhibitory efficacy of endophytic Bacillus subtilis EDR4 against Sclerotinia sclerotiorum on rapeseed. Biological Control, 78: 67-76. https://doi.org/10.1016/j.biocontrol.2014.07.012

Chen X., Pizzatti C., Bonaldi M., Saracchi M., Erlacher A., Kunova A., Berg G., Cortesi P. 2016. Biological control of lettuce drop and host plant colonization by rhizospheric and endophytic Streptomvcetes. Frontiers in Microbiology, 7: 714. https://doi.org/10.3389/fmicb.2016.00714

Collange B., Navarrete M., Montfort F., Mateille T., Tavoillot J., Martiny B., Tchamitchian M. 2014. Alternative cropping systems can have contrasting effects on various soil-borne diseases: relevance of a systemic analysis in vegetable cropping systems. Crop Protection, 55: 7-15. https://doi.org/10.1016/j.cropro.2013.10.002

Derbyshire M. C., Denton-Giles M. 2016. The control of sclerotinia stem rot on oilseed rape (Brassica napus): current practices and future opportunities. Plant Pathology, 65 (6): 859-877. https://doi.org/10.1111/ppa.12517

Duman K., Soylu S. 2019. Characterization of antagonistic and plant growth-promoting traits of endophytic bacteria from bean plants against Pseudomonas syringae pv. phaseolicola. Plant Protection Bulletin, 59 (3): 59-69. https://doi.org/10.16955/bitkorb.597214

Eljounaidi K., Lee S. K., Bae H. 2016. Bacterial endophytes as potential biocontrol agents of vascular wilt diseases - review and future prospects. Biological Control, 103: 62-68. https://doi.org/10.1016/j.biocontrol.2016.07.013

Fatouros G., Gkizi D., Fragkogeorgi G. A., Paplomatas E. J., Tjamos S. E. 2018. Biological control of Pythium, Rhizoctonia and Sclerotinia in lettuce: association of the plant protective activity of the bacterium Paenibacillus alvei K165 with the induction of systemic resistance. Plant Pathology, 67 (2): 418-425. https://doi.org/10.1111/ppa.12747 
Geraldine A. M., Lopes F. A. C., Carvalho D. D. C., Barbosa E. T., Rodrigues A. R., Brandao R. S., Ulhoa C. J., M. Lobo Jr. 2013. Cell wall-degrading enzymes and parasitism of sclerotia are key factors on field biocontrol of white mold by Trichoderma spp. Biological Control, 67 (3): 308-316. https://doi.org/10.1016/j.biocontrol.2013.09.013

Gupta C. P., Dubey R. C., Kang S. C., Maheshwari D. K. 2001. Antibiosis-mediated necrotrophic effect of Pseudomonas $\mathrm{GRC}_{2}$ against two fungal plant pathogens. Current Science, 81 (1): 91-94. https://www.jstor.org/stable/24105010

Hao J. J., Subbarao K. V. 2005. Comparative analyses of lettuce drop epidemics caused by Sclerotinia minor and S. sclerotiorum. Plant Disease. 89 (7): 717-725. https://doi.org/10.1094/PD-89-0717

Hernández-León R., Rojas-Solís D., Contreras-Pérez M., Orozco-Mosqueda M. del C., Macías-Rodríguez L. L., Reyes-de la Cruz H., Valencia-Cantero E., Santoyo G. 2015. Characterization of the antifungal and plant growthpromoting effects of diffusible and volatile organic compounds produced by Pseudomonas fluorescens strains. Biological Control, 81: 83-92. https://doi.org/10.1016/j.biocontrol.2014.11.011

Hu X., Roberts D. P., Xie L., Maul J. E., Yu C., Li Y., Jiang M., Liao X., Che Z., Liao X. 2014. Formulation of Bacillus subtilis by BY-2 suppresses Sclerotinia sclerotiorum on oilseed rape in the field. Biological Control. 70: 54-64. https://doi.org/10.1016/j.biocontrol.2013.12.005

Imriz G., Ozdemir F., Karaca M. S., Taş M. N., Topal İ., Ercan B. 2020. Biological control potential of rhizosphere bacteria with ACC-deaminase activity against Fusarium culmorum in wheat. Zemdirbyste-Agriculture, 107 (2): 105-112. https://doi.org/10.13080/z-a.2020.107.014

Ji S. H., Paul N. C., Deng J. X., Kim Y. S., Yun B- S., Yu S. H. 2013. Biocontrol activity of Bacillus amyloliquefaciens CNU114001 against fungal plant diseases. Mycobiology, 41 (4): 234-242. https://doi.org/10.5941/MYCO.2013.41.4.234

Kamal M. M., Lindbeck K. D., Savocchia S., Ash G. J. 2015. Biological control of sclerotinia stem rot of canola using antagonistic bacteria. Plant Pathology, 64 (6): 1375-1384. https://doi.org/10.1111/ppa.12369

Kumar P., Dubey R. C., Maheshwari D. K. 2012. Bacillus strains isolated from rhizosphere showed plant growth promoting and antagonistic activity against phytopathogens. Microbiological Research, 167 (8): 493-499. https://doi.org/10.1016/j.micres.2012.05.002

Kurt Ş., Uysal A., Kara M., Soylu S., Soylu E. M. 2017. Natural infection of potato by Sclerotinia sclerotiorum causing stem rot disease in Turkey. Australasian Plant Disease Notes, 12: 39. https://doi.org/10.1007/s13314-017-0266-1

Lee K.-Y., Kong H.-G., Choi K.-H., Lee S.-W., Moon B.-J. 2011. Isolation and identification of Burkholderia pyrrocinia CH-67 to control tomato leaf mold and damping-off on crisphead lettuce and tomato. The Plant Pathology Journal, 27 (1): 59-67.

https://doi.org/10.5423/PPJ.2011.27.1.059

Loewen P. C., Switala J., Fernando W. G. D., de Kievit T. 2014. Genome sequence of Pseudomonas brassicacearum DF41. Genome Announcements, 2 (3): e00390-14. https://doi.org/10.1128/genomeA.00390-14

Ni Y., Guo Y.-J., Wang J., Xia R.-E., Wang X.-Q., Ash G., Li J.-N. 2014. Responses of physiological indexes and epicuticular waxes of Brassica napus to Sclerotinia sclerotiorum infection. Plant Pathology, 63 (1): 174-184. https://doi.org/10.1111/ppa.12060

Oliver C., Hernandez I., Caminal M., Lara J. M., Fernandez C. 2019. Pseudomonas putida strain B2017 produced as technical grade active ingredient controls fungal and bacterial crop diseases. Biocontrol Science and Technology, 29 (11): 1053-1068.

https://doi.org/10.1080/09583157.2019.1645304
Ordóñez-Valencia C., Ferrera-Cerrato R., Quintanar-Zúñiga R. E., Flores-Ortiz C. M., Guzmán G. J. M., Alarcón A., Larsen J., García-Barradas O. 2014. Morphological development of sclerotia by Sclerotinia sclerotiorum: a view from light and scanning electron microscopy. Annals of Microbiology, 65: 765-770.

https://doi.org/10.1007/s13213-014-0916-x

Panda A., Kurapati S., Samantaray J. C., Myneedu V. P., Verma A., Srinivasan A., Ahmad H., Behera D., Singh U. B. 2013. Rapid identification of clinical mycobacterial isolates by protein profiling using matrix assisted laser desorption ionization-time of flight mass spectrometry. Indian Journal of Medical Microbiology, 31 (2): 117-122.

https://doi.org/10.4103/0255-0857.115217

Pane C., Villecco D., Campanile F., Zaccardelli M. 2012. Novel strains of Bacillus, isolated from compost and compostamended soils, as biological control agents against soilborne phytopathogenic fungi. Biocontrol Science and Technology, 22 (12): 1373-1388. https://doi.org/10.1080/09583157.2012.729143

Rothmann L. A., McLaren N. W. 2018. Sclerotinia sclerotiorum disease prediction: a review and potential applications in South Africa. South African Journal of Science, 114 (3-4): 9. https://doi.org/10.17159/sajs.2018/20170155

Santoyo G., Moreno-Hagelsieb G., Orozco-Mosqueda M. del C., Glick B. R. 2016. Plant growth-promoting bacterial endophytes. Microbiological Research, 183: 92-99. https://doi.org/10.1016/j.micres.2015.11.008

Singhal N., Kumar M., Kanaujia P. K., Virdi J. S. 2015. MALDI-TOF mass spectrometry: an emerging technology for microbial identification and diagnosis. Frontiers in Microbiology, 6: 791 .

https://doi.org/10.3389/fmicb.2015.00791

Smolińska U., Kowalska B. 2018. Biological control of the soilborne fungal pathogen Sclerotinia sclerotiorum - a review. Journal of Plant Pathology, 100: 1-12. https://doi.org/10.1007/s42161-018-0023-0

Soylu S., Bozkurt İ. A. 2019. Determination of antagonistic potential of epiphytic and endophytic bacterial isolates against apple crown gal disease agent Rhizobium radiobacter. Journal of Tekirdag Agricultural Faculty, 16 (3): 348-361 (in Turkish).

https://doi.org/10.33462/jotaf.556256

Soylu S., Soylu E. M., Kurt S., Ekici O. K. 2005. Antagonistic potentials of rhizosphere-associated bacterial isolates against soil-borne diseases of tomato and pepper caused by Sclerotinia sclerotiorum and Rhizoctonia solani. Pakistan Journal of Biological Sciences, 8 (1): 43-48. https://doi.org/10.3923/pjbs.2005.43.48

Soylu S., Yigitbas H., Soylu E.M., Kurt Ş. 2007. Antifungal effects of essential oils from oregano and fennel on Sclerotinia sclerotiorum. Journal of Applied Microbiology, 103 (4): 1021-1030. https://doi.org/10.1111/j.1365-2672.2007.03310.x

Soylu S., Sertkaya E., Üremiş İ., Bozkurt İ. A., Kurt Ş. 2017. Prevalence and incidence of important disease agents, insects and weed species in lettuce (Lactuca sativa L.) growing fields in Hatay Province. Journal of Agricultural Faculty of Mustafa Kemal University, 22 (1): 23-33 (in Turkish).

Sülü S. M., Bozkurt İ. A., Soylu S. 2016. Bacterial endophytes as plant growth promoting and biological control agents. Journal of Agricultural Faculty of Mustafa Kemal University, 21 (1): 103-111 (in Turkish).

Wang H., Wang Z., Liu Z., Wang K., Xu W. 2021. Membrane disruption of Fusarium oxysporum $\mathrm{f}$. sp. niveum induced by myriocin from Bacillus amyloliquefaciens LZN01. Microbial Biotechnology, 14 (2): 517-534. https://doi.org/10.1111/1751-7915.13659 
Youcef-Ali M., Kacem-Chaouche N., Dehimat L., Bataiche I., Kara-Ali M., Cawoy H., Thonart P. 2014. Antifungal activity and bioactive compounds produced by Bacillus mojavensis and Bacillus subtilis. African Journal of Microbiology Research, 8 (6): 476-484. https://doi.org/10.5897/AJMR2013.6327

Zhao X., Zhao X., Wei Y., Shang Q., Liu Z. 2012. Isolation and identification of a novel antifungal protein from a rhizobacterium Bacillus subtilis strain F3. Journal of Phytopathology, 161 (1): 43-48. https://doi.org/10.1111/jph.12015

Zhu Z.-Q., Zhou F., Li J.-L., Zhu F.-X., Ma H.-J. 2016. Carbendazim resistance in field isolates of Sclerotinia sclerotiorum in China and its management. Crop Protection, 81: $115-121$.

https://doi.org/10.1016/j.cropro.2015.12.011

\title{
Sẻjamosios salotos endofitinių bakterijų antagonistinis potencialas nuo salotų sklerotinio puvinio sukẻlèjo Sclerotinia sclerotiorum
}

\author{
S. Soylu ${ }^{1}$, M. Kara ${ }^{1}$, A. Uysal ${ }^{2}$, Ş. Kurt ${ }^{1}$, E. M. Soylu ${ }^{1}$ \\ ${ }^{1}$ Hatay Mustafa Kemal universiteto Žemès ūkio fakultetas, Turkija \\ ${ }^{2}$ Hatay Mustafa Kemal universiteto Augalų sveikatos klinikos ir tyrimų centras, Turkija
}

\section{Santrauka}

Ivvertintas iš sèjamosios salotos (Lactuca sativa L.) išskirtų endofitinių bakterijų biologinès kontrolès efektyvumas nuo sklerotinio puvinio sukèlejo Sclerotinia sclerotiorum in vitro ir in vivo sąlygomis. Nustatytas endofitinių bakterijų antagonistinis veiksmingumas slopinant micelio augimą bei skleročių daigumui ir sklerotinio puvinio sukèlejo S. sclerotiorum sukeliamų ligų paplitimui in vitro bei in vivo. Iš ịvairių vizualiai sveikų salotų audinių iš viso buvo išskirti 48 endofitinių bakterijų izoliatai. S. sclerotiorum micelio augimą ir skleročių daigumas in vitro slopino 18 bakterijų izoliatų. Nustatyta, kad veiksmingiausi buvo Bacillus subtilis ir B. amyloliquefaciens izoliatai, kurie reikšmingai $68,1-83,1 \%$ slopino micelio augimą, 82,7-89,6 \% skleročių daigumą ir 55,7-75 \% $S$. sclerotiorum paplitimą in vitro bei in vivo. Be to, dviguboje kultūroje netoli slopinimo zonos grybo micelis buvo tankesnis ir tamsesnès spalvos. Dviguboje kultūroje netoli slopinimo zonos B. subtilis ir B. amyloliquefaciens izoliatai sukèlè reikšmingų morfologinių hifų pakitimų, pavyzdžiui, susitraukimą ir perforaciją.

Endofitinių bakterijų reikšmingas micelio augimo, skleročių daigumo ir sklerotinio puvinio paplitimo slopinimas rodo, kad B. subtilis ir B. amyloliquefaciens izoliatai gali būti naudojami per dirvožemị plintančių grybinių ligų biologinei kontrolei.

Reikšminiai žodžiai: antagonistai, biologinè kontrolè, endofitai, Lactuca sativa, Sclerotinia sclerotiorum. 